\title{
The importance of habitat features in low-relief continental shelf environments
}

\author{
Richard J. MALATESTA ${ }^{a *}$, Peter J. AUSTER ${ }^{b}$ \\ ${ }^{\text {a }}$ Sea Education Association, P.O. Box 6, Woods Hole, Massachusetts 02543, USA \\ Present address: The School for Field Studies, 16 Broadway, Beverly, Massachusetts 01915, USA \\ ' NOAA's National Undersea Research Center, The University of Connecticut at Avery Point, Groton, Connecticut \\ 06340, USA
}

Revised 8 March 1999; accepted 19 April 1999

\begin{abstract}
Benthic habitats can be loosely divided into low and high relief based upon gross bottom topography. While fish community studies in high relief environments such as coral reefs have been extensively studied using in situ visual analysis, most studies of low relief environments have utilized trawl-based methodologies. Such studies while valuable, are unable to detect small-scale variations in habitat availability and faunal responses to that variation. This paper presents the availability of other techniques, ranging from visual surveys to sonar and bathymetric analysis, which allow researchers to address questions of habitat utilization in low relief environments. (C) 1999 Ifremer / CNRS / IRD / Éditions scientifiques et médicales Elsevier SAS
\end{abstract}

\section{habitat / fish community / topography}

Résumé - Importance des caractéristiques de I'habitat dans les environnements à faibles reliefs du plateau continental. À partir de la topographie des fonds marins, les habitats benthiques peuvent être grossièrement divisés entre des environnements à faibles reliefs ou à reliefs élevés. Alors que des analyses visuelles in situ ont été largement utilisées dans l'étude de communautés de poissons composant les environnements à reliefs élevés tels que les récifs coralliens, la plupart des études dans des environnements à faibles reliefs ont été réalisées par des méthodologies fondées sur le chalutage. Malgré leur intérêt, ces techniques ne détectent pas la variabilité à petite échelle de l'habitat et les réponses de la faune. Le présent travail présente d'autres méthodes, allant du relevé visuel à la détection par sonar et à l'analyse bathymétrique, qui permettent d'étudier l'utilisation de l'habitat dans les environnements à faibles reliefs. (C) 1999 Ifremer / CNRS / IRD / Éditions scientifiques et médicales Elsevier SAS

\section{habitat / communauté de poissons / topographie}

The first impression of a benthic habitat often comes from a look at a bathymetric chart. At one extreme, areas with widely spaced isobaths (lines of equal depth) which lack other bathymetric traits are often termed 'featureless' or 'low relief'. At the other extreme, areas of closely spaced or wildly fluctuating isobaths indicate dramatic subsurface features of high relief such as continental shelf submarine canyons or volcanic seamounts. Habitats with such complex topography often contain associated, conspicuous faunal compositions. Examples include geo- logical features such as rock outcrops [20], the steep walls of submarine canyons [7] and well known biotic habitat examples such as coral reef [14] and kelp bed habitats [8]. In these high relicf environments, visual habitat assessment is often a critical tool for fisheries management.

The broad continental shelf along the east coast of the United States is an excellent example of a low relief habitat. The fish communities of this region have been studied for years with fisheries managers long relying on

* Correspondence and reprints: rmalatesta $₫$ fieldstudies.org 
fish landings and trawl surveys to assess fish stocks in this area. Habitat studies, at least at the spatial scale of those cited above, are relatively rare. Why is this? The implicit assumption has been that because it is apparently absent, topographical complexity must not be important in low relief habitats.

A very practical way to view the division between low and high relief environments can be based on fishing techniques themselves. In this case, the major technique for the east coast groundfish fishery is the otter trawl. Any sort of bottom which allows a trawl to pass over can be functionally defined as low relief, otherwise the net is ripped or snagged and the bottom should be deemed high relief and avoided. Using this sort of informal assessment, most of the northeast coast continental shelf would be considered 'low relief', and happens to be heavily fished. This idea is further reinforced by a variety of studies, many of which actually incorporate trawl data. These studies demonstrate a variety of large-scalc physical and biological factors structuring mesoscale $(1-1000 \mathrm{~km})$ faunal distributions on low relief continental shelf habitats. Factors which have been shown to be important include depth, hottom water temperature, and broad geographical region $[6,12,13]$, seasonal associations [17], as well as sediment type $[16,20]$. Using these studies, benthic habitat can be viewed as a relatively large-scale phenomena in which fish distributions are determined by latitude, whether the bottom is muddy or sandy, or by narrow versus wide fluctuations in temperature. Other large scale processes such as gradual bathymetric changes, large geologic features (e.g. banks and basins), and changes in sedimentary regime are likewise impor$\operatorname{tant}[18,20]$.

Variations at the mesoscale are also an important factor. The use of trawl-based studies is an efficient way to demonstrate relative changes in fish density and distribution in relation to such variation. These studies do however have an inherent spatial bias. Any data taken from a trawl are value-averaged over the trawl distance (e.g. density for a given species is the number of individuals of that species caught in the trawl, per the area trawled). This necessarily ignores any phenomena on a scale smaller than that of the trawl length. In addition, trawl-based studies cannot address questions of small-scale topographic structure in low relief environments because the trawl sampling cannot 'recognize' such features.

Such bias is an important consideration, because low relief does not necessarily equal no relief. Low relief continental shelf habitats contain numerous features which provide distinct topographic relief and potential habitat variability (and value) at much smaller scales. At the smallest scales, these features include but are not limited to shell, biogenic feeding depressions, storm-generated sand waves and various sessile biological structure such as amphipod tubes and sponges [2, 4]. When discrete structures such as these serve as habitats to benthic and demersal organisms they are termed 'microhabitats' (sensu [1]). Within the context of a trawl-based study, we can at best make some guesses about the presence of microhabitat features (such as the presence of shells or sponges) by looking in the trawl bycatch, while completely missing others (such as amphipod tubes or stormgenerated sand waves) which pass through or are passed over by the trawl.

Previous studies have shown these small-scale microhabitat features to have significant effects on benthic faunal distributions [2, 4]. Most often in these studies, the presence of a given microhabitat feature serves to enhance faunal densities relative to adjacent areas which lack those features. This is especially true for smaller fauna and juveniles of larger species which utilize the benthos for feeding and cover.

Microhabitat features vary in their spatial extent. The studies cited above noted positive faunal responses to habitat features ranging from single bivalve shells in featureless sand to expanses of storm-induced sand waves extending over hundreds of meters. Examples of topographic change and habitat structural elements can be found at any spatial scale ranging from meters to hundreds of kilometers [9].

As we expand our scale from the single individual organism interacting with a specific habitat feature to populations responding to suites of hahitat features over large scales, the techniques we employ must change (table $)$. Techniques which are effective at examining small-scale processes (e.g. direct observation using ROVs and submersibles) are difficult or impossible to use at larger scales. Identification of larger scale habitat variation requires remote sensing techniques such as sector or side scan sonar. At the largest scales, variations in bathymetry may be important to fauna not only in the absolute changes in depth, but also for more subtle aspects of bathymetric variability. For these sorts of estimates, techniques which measure fractal dimension and rugosity may be required $[5,10]$. At the largest end of this spectrum wc arc considering the same spatial scales covered by the trawl-based studies discussed above. 
Making the link between these various spatial scales and between the vastly different methodologies outlined in table $I$ is difficult. While large scale, remote techniques such as side scan sonar can detect variations in geological structures (thus identifying different potential habitats), whether these variations are structuring animal distributions requires visual groundtruthing (i.e. small scale visual techniques) to determine if fauna are responding to these variations. In addition each technique has physical limitations and biases. For example, side scan sonar techuiques are able to see some important features (e.g. rocky outcrops) much more easily than other more subtle features (c.g. storm gencrated sand waves) [20].

There are temporal considerations which should be made as well. Habitat features, especially the small-scale features discussed here, are not static through time. Biologically features such as sponges, amphipod tubes and feeding pits will appear and disappear with respect to the factors influencing individual species' population dynamics. Storms create and destroy sand waves while burying or exposing rock outcrops and shell cover. Additionally, human-caused factors, most notably trawling activities, are a potentially large factor affecting habitat characteristics in these low-relief environments. Trawling over time has been shown to strongly effect community composition in a variety of continental shelf ecosystems
[19]. The physical action of trawling, dredging and other bottom fishing activity can disperse and destroy many small scale habitat features. Benthic environments undisturbed by trawling activity have been shown to have greater concentrations of epibenthic fauna and potential small-scale habitats [3]. What is not known is how long it takes for bottom to 'recover', [15] that is to proceed from recently trawled to a state where small-scale habitat types have returned to unimpacted densilies.

These observations and questions have potentially important management implications. We can make the case that the continental shelf, while low relief, is not a homogenous environment but instead contains a variety of habitat types that exist at different spatial scales. Furthermore, at least some fauna respond to the presence of habitat variation. The next step is to evaluate the importance of these observations. Are fauna using benthic habitat continuously, or only during a portion of their life history? Is habitat use seasonal? Are these habitats 'essential' (sensu [11]), that is does a shortage of such habitat represent a bottleneck to the population dynamics in species of interest? Managers making decisions, particularly those that involve closing areas to trawling and other activities that impact the bottom, need the answers to these questions in order to understand the importance of low relief benthic habitat to the species they manage.

Table I. Assessment techniques which take into account habitat features at a variety of spatial scales within low relief continental shelf environments.

\begin{tabular}{|c|c|c|c|c|}
\hline Technology & Type of Data & Analysis Methodology & Spatial Scale & Management Implications \\
\hline Video/Still Imagery & $\begin{array}{l}\text { Simultaneous habitat type } \\
\text { (biotic and abiotic) and } \\
\text { faunal distributions }\end{array}$ & $\begin{array}{l}\text { Categorical habitat } \\
\text { distributions, faunal } \\
\text { associations and density }\end{array}$ & $1-100 \mathrm{~m}$ & $\begin{array}{l}\text { Correlation of fauna with } \\
\text { microhabitat features and } \\
\text { fine scale density structure }\end{array}$ \\
\hline Sector Scanning Sonar & $\begin{array}{l}\text { Grey scale reflectance } \\
\text { (fine scale survey) }\end{array}$ & $\begin{array}{l}\text { Qualitative interpretation } \\
\text { of small scale features }\end{array}$ & $10-100 \mathrm{~m}$ & $\begin{array}{l}\text { Time series analysis of changes } \\
\text { in habitat features } \\
\text { (coincident with video survey) }\end{array}$ \\
\hline Sidescan Sonar & $\begin{array}{l}\text { Grey scale reflectance - } \\
\text { wide area survey }\end{array}$ & $\begin{array}{l}\text { Comparison of mean } \\
\text { gray scale values }\end{array}$ & $10-1000 \mathrm{~m}$ & $\begin{array}{l}\text { Correlation of fauna with } \\
\text { sediment type and texture }\end{array}$ \\
\hline $\begin{array}{l}\text { Bathymetry (Leadline, } \\
\text { Single Transducer } \\
\text { Sonar, Multibeam) }\end{array}$ & Bathymetric contours & $\begin{array}{l}\text { Fractal geometry, } \\
\text { rugosity, slope }\end{array}$ & $100-1000 \mathrm{~m}$ & $\begin{array}{l}\text { Correlation of faunal } \\
\text { distributions based on bank } \\
\text { features and depth }\end{array}$ \\
\hline
\end{tabular}

\section{REFERENCES}

[1] Auster P.J., Malatesta R.J., LaRosa S.C., Cooper R.A., Stewart L.L., Microhabitat utilization by the megafaunal assemblage at a low relief outer continental shelf site, Middle Atlantic Bight, USA, J. Northwest Fish. Soc. 11 (1991) 59-69.
[2] Auster P.J., Malatesta R.J., LaRosa S.C., Patterns of microhabitat utilization by mobile megafauna on the southern New England (USA) continental shelf and slope, Mar. Ecol. Prog. Ser. 127 (1995) 77-85. 
[3] Auster P.J., Malatesta R.J., Langton R.W., Watling L., Valentine P.C., Donaldson C.L.S., Langton E.W., Shepard A.N., Babb I.G., Impacts of mobile fishing gear on seafloor habitats in the Gulf of Maine (Northwest Atlantic): Implications for conservation of fish populations, Rev. Fish. Sci. 4 (1996) 185202.

[4] Auster P.J., Malatesta R.J., Donaldson C.L.S., Distributional responses to small-scale habitat variability by early juvenile silver hake, Merluccius bilinearis, Environ. Biol. Fishes 50 (1997) 195-200.

[5] Auster P.J., Michalopoulos C., Robertson R., Valentine P.C., Joy K., Cross V., Use of acoustic methods for classification and monitoring of seafloor habitat complexity: description of approaches, in: Linking Protected Areas with Working Landscapes, Science and Management of Protected Areas Association, Wolfville, Nova Scotia, in press.

[6] Colvocoresses J.A., Musick J.A., Spccies associations and community composition of Middle Atlantic Bight continental shelf demersal fishes, Fish. Bull. U.S. 82 (1984) 295-313.

[7] Cooper R., Shepard A.N., Valentine P., Uzmann J.R., Hulbert A., Pre and post drilling bench marks and monitoring data of ocean floor fauna, habitats, and contaminant loads on Georges Bank and its submarine Canyons, in: Symposia Series of Undersea Research, NOAA, Office of Undersea Research, Rockville, MD, 1987, pp. 17-48.

[8] Ebling A.W., Larson R.F., Alevizon W.S., Bray R.N., Annual variability of reef-fish assemblages in kelp forests off Santa Barbara, California, Fish. Bull. U.S. 78 (1980) 361-377.

[9] Greene H.G., Yoklavich M.M., Starr R., O'Connell V., Wakefield W., Sullivan D., Mc Rea J., Cailliet G.M., A classification scheme for deep seafloor habitats, Oceanol. Acta 22 (6) 1999 663-678

[10] Goff J.A., Tucholke B.E., Multiscale spectral analysis of bathymetry on the flank of the Mid-Atlantic ridge: modification of the seafloor by mass wasting and sedimentation, $J$. Geophys. Res. 102 (1997) 15447-15462.

[11] Langton R.W., Steneck R.S., Gotceitas V., Juanes F., Lawton $P$., The interface between fisheries research and habitat management, N. Amer. J. Fish. Management 16 (1996) 1-7.
[12] Overholtz W.J., Tyler A.V., Long-term responses of the demersal fish assemblages of Georges Bank, Fish. Bull. U.S. 83 (1985) 507-520.

[13] Phoel W.C., Community structure of demersal fishes on the inshore U.S. Atlantic continental shelf: Cape Ann, Massachusetts to Cape Fear, North Carolina, PhD Dissertation, College of William and Mary, 1986.

[14] Sale P.F., The structure of communities of fish on coral reefs and the mcrit of a hypothesis testing, manipulative approach to ecology, in: Strong Jr. D.R. et al. (Eds.), Ecological Communities, Conceptual Issues and the Evidence, Princeton University Press, Princeton, New Jersey, 1984, pp. 478-490.

[15] Schwinghamer P., Gordon Jr. D.C., Rowell T.W., Prena I., McKeown D.L., Sonnichsen G., Guignè J.Y., Effects of experimental otter trawling on surficial sediment properties of a sandy-bottom ecosystem on the Grand Banks of Newfoundland, Conserv. Biol. 12 (1998) 1215-1222.

116] Scott J.S., Selection of bottom type by groundfishes of the Scotian Shelf, Can. J. Fish. Aquat. Sci. 39 (1982) 943-947.

[17] Tyler A.V., Periodic and resident components in communities of Atlantic fishes, J. Fish. Res. Board Can. 29 (1971) 9971003 .

[18] Valentine P.C., Schmuck E.A., Geological mapping of biological habitats on Georges Bank and Stellwagen Bank, Gulf of Maine region, in: O'Connell V. (Ed.), Workshop on the use of side-scan sonar for fisheries research. Alaska Department of Fish and Game Technical Report, 1994, pp. 15-18.

[19] Watling L., Norse E.A., Disturbance of the seabed by mobile fishing gear: a comparison to forest clearcutting, Conserv. Biol. 12 (1998) 1180-1197.

[20] Yoklavich M.M., Cailliet G.M., Greene H.G., Sullivan D.s Interpretation of side-scan sonar records for rockfish habitat analysis: examples from Monterey Bay, in: O'Connell $\mathrm{V}$. (Ed.), Workshop on the use of side-scan sonar for fisheries research, Alaska Department of $\Gamma i s h$ and Game Technical Report, 1994, pp. 19-24. 